\title{
Modernism Technique of Women in Love
}

\author{
Youjin Ge \\ Department of International Exchange and Cooperation, Yibin University, Yibin, 644000, China
}

Keywords: Women in Love. Modernism. D. H. Lawrence

\begin{abstract}
D. H. Lawrence was an excellent modernist, and he played an important role in American and English modernist literature. Modernism technique has been fully applied in Women in Love, a magnum opus of $\mathrm{D}$. H. Lawrence. This article would discuss modernism technique in three aspects: ideological contents, themes and artistic expression.
\end{abstract}

\section{Introduction}

Modernism is the most powerful philosophical movement in Western society in the late $19^{\text {th }}$ and early $20^{\text {th }}$ centuries with plenty modernists. D. H. Lawrence has been classified as modernist by a large number of researchers, and his work indeed played an important role in modernism development in western literature, especially the work Women in Love. Now, I would like to talk about the modernism technique reflected in the book in the following three aspects.

\section{Modernism techniques shown in ideological contents.}

\section{Destruction of human nature in industrial civilization}

Most of modernists have negative attitudes towards modern industry civilization. They thought industry civilization had destroyed elegant rurality, and distorted human freedom strongly which made people lose their faith and become salves of substance with nothingness in their spiritual world. D. H. Lawrence was also in the horrors of it, and he gave a true picture of broken scenario in his work Women in Love. Lawrence figured out that not only the natural world had been destroyed by industry civilization, but the human natural also been distorted depressively, and all these had been concentrated expressed in the portrait of Gerald. In this book, coal-mine heir Gerald gave up his father's original flexible management method, made a series of changes, namely modern industry management measures, to oppress works for squeezing labor force till they dead. However, the success of reforming did not bring happiness to Gerald; on the contrary, he was isolated and alienated away from his workers. Gerald was filled with emptiness and horrors, and this made him a representative and victim of modern industry civilization. What he advocated was power and position, but on his way to these, he became a body without heart, and died in a world of ice and snow. This is exactly what Lawrence trying to say that industry civilization had suffered people greatly. In the Lawrence's point of view, human beings should be full of energy, however, with the depression acted by industry civilization, people became cruel and merciless.

\section{Further depict character's inner world.}

Lawrence was famous for his psychology creation in his work. He always focused on the micro world of characters to show their psychological change process; hence the spiritual crisis and unendurable inner world flew out of the paper. In the work Women in Love, Lawrence spent most words on description of characters' inner world to show complicated mentality of westerners, and made it a record of most heavy experience in accordance with the writer himself.

\section{Modernism techniques shown in themes}

Fully display of tragic social reality.

Affected by Bergson's Intuitionism and psychology theories of Freud, rebel consciousness of traditional literature ideas and creation standards were called up by modernists in western countries in 
the early of last century. They abandoned the general mode of expressing outer world of characters and to put efforts in the real inner world, which would repeal the complicated mentality of westerners. This had been presented in an early work of Lawrence- Sons and Lovers, which showed sense of alienation of westerners, as well as reflected how disgusting the reality was. When it came to the peak work - Women in Love, Lawrence s reached his high-point in detailed painting the real world. In this work, he endeavored to demonstrate the complicated indefinable inner world to readers. For instance, in the first chapter, readers could deeply feel the strong sense of self-awareness of Gudrun. Inner emotions of a tortured soul have been displayed vividly in front of readers, to make us shock for her complicated feelings and tragic experiences. Hence, we could deeply experience the emotions and emotion changes of characters.

\section{Emphasis on sex}

Modernism techniques of Women in Love are emphasis on sex, which reflected his study in modern industry civilization squeezing, and corrupted sex relationship and sexual psychology. In fact, Lawrence made lot descriptions in his numerous works. Therefore, his representative works The Rainbow, Lady Chatterley's Lover, Women in Love etc. were repeatedly banned, and he also was treated as a porn writer. However, if you truly understand Lawrence's sexual views, you can find out reasons for his action, and take an objective attitude to read sex scenes. Lawrence believed that sex and beauty is the same thing, just like flame and fire. Once you are tired of sex that means you are tired of beauty. As long as you fell in love with beauty of lie, you will respect sex. To Lawrence, sex is not dirty, and only the person who takes sex is falling, sex becomes dirty. Therefore, sex itself is not eroticism, and definitely different from obscene. Reasonable sexual arousal has uncountable values to human daily life, the world would be extinguished for loss of sex, but eroticism is blasphemy to human beings. With this view of sex, Lawrence never took sex as his ultimate aim; he used sex as a discussion theme to find a right way to build harmonious sexual relationship between people, especially between men and women. Hence, a new pathway to a new ideal society could be pointed out. In the work of Women in Love, Lawrence described by two couples sexual love contrast raised extremely criticism of industry civilization and highly praise of harmonious sexual relationship.

\section{Modernism techniques shown in artistic expression}

\section{Loose disorder in surface structure}

One of the basic features in Modernism is to make narrative form hazy obscure, and the surface structure is in loose disorder. Referring to this book, Women in Love apparently has modernism features. With thirty-one chapters and more than four hundred thousand words, the book captured thirty-one slices of main characters' lives instead of narrating either in time sequence or natural development order of events. It seems that the stories are lack of logical interrelated causal relationship, as a matter of fact, the slices made up a series of stories with counterpoint, which would introduce essential power to the fictional structure that with loose disorder surface. By reading carefully, readers could figure out lots of separated scenarios, dispersed and irrelevant, would be inner connected via symbolism contained, and they became the latitude and longitude of deep structure. For example, in Chapter Nine, at the crossing of railway, Gerald tamed a mare in front of Ursula and Gudrun, by this way Gerald showed his courage and power to Gudrun. While in Chapter Fourteen, Gudrun scared off Gerald's bull in a crazy way to respond him. And in Chapter Eighteen, Gerald and Gudrun made concerted efforts in hurting a wild rabbit. Above three scenes were laid in three chapters respectively, and there won't be any connections in the surface, but in the deep structure they have a uniform symbolic meaning. Serous conflict in sub-consciousness of the two had been revealed opportunely. All messy scenes in the book supported each other, which made internal structure harmony and showed the planning ability of Lawrence with beautiful thoughts of modernism. Meanwhile, the loose disordered surface structure performed in the open end of Women in Love. The relationship of Gerald and Gudrun ended with Gerald's death, while, Birkin was still on his way to pursuit to perfect sexual relationship, even he had already married to Ursula and obsessed by emotional conflict with her. 


\section{Unique power in symbolism}

Symbolism is an important part of artistic expression and popular among novelists from all periods. Nevertheless, traditional symbolic device has definite meanings, and there are always similarities between indication and the one be referred to. But in modernism, symbolic meanings are hazy obscure, and it is difficult to identify the real messages. Modernistic symbolism is always applied to express the complicated inner world of characters by writers, which is a method of composition that could to show their unconscious mental activities. Lawrence explored dark worlds inside humans in his works for readers. In order to make readers observe inner-most thoughts and feel the complicated ineffable real inner world of characters directly, he used a great number of token method, metaphor and symbolism and gave them special implication. The application of above methods could present the ineffable unconscious mental activities visually, and make the work unique symbolic.

Full text of Women in Love is almost covered by image symbols, yet symbolic meaning has become the key point of interpretation. Moon is the most common symbol in Lawrence works, it stands for the power of women. In the book of Women in Love, Birkin roamed to the side of Willey Water, after seeing the shadow of moon, a strong aversion to women kindled inside of him. Because he thought women in love were too possessive and they would like to completely control and monopolize their partners. The women were like Great Mother to make decisions all on her own. This was far from Birkin's idea of harmony sexual relationship between men and women. Hence, he wished he could smash the shadow of moon, embodiment of female, by lapidation. However, as a centre, the glint intact moon floated in the water like a hot white fireball struggling but completed. Description above offered a vivid picture of intense psychological warfare between Birkin and Ursula, and the inner world of characters was profoundly exhibited, which could not be done by traditional symbolic device. Horses are common symbols in the book as well. Horses could vividly express ups and downs in the most secret spirit world. In Chapter Nine, as Gerald taming the mare, Gudrun was spinning around for the bloody scenario, even lost conscious; and when she waking up, she turned out to be peace and cold. She sat on the sidelines while the man was still fighting with mare. Her heart was cold as stones. Gerald was planned to tame Gudrun as taming the mare, but he misjudged. This scenario profoundly revealed serous sexual conflict in sub-consciousness of Gerald and Gudrun. Thereby, the final episode could be indicated.

In the mean time, Lawrence combined prototype from Bible with symbol to express rich connotation. Women in Love was based on Apocalypse from the Bible. The couple of Gerald and Gudrun are the symbol of destruction. In the book, they always come out together with white, water, rain, snow etc. destruction image and an atmosphere of terror before catastrophe was delivered. However, Birkin and Ursula are the symbol of new hope. Beautiful images such as butterflies, grassland and trees come up from the perfect relationship of Birkin and Ursula. The significant comparison between death and new born generated a great power in readers' heart in Women in Love, which can be treated as a modern apocalypse.

\section{Conclusion}

In a word, Women in Love has been acknowledged as a peak work for the writer Lawrence. Through the discussion above, significant modernism has been shown in artistic expression in both ideological contents and themes. That is to say full development of modernism creation theme has been done in this book, and this makes it a master work of world literature.

\section{References}

[1] Zhao Yuan: Discussion on Inclination of Modernism in Lawrence's book 'Women in Love', Journal of Language and Literature Studies, 2010 (4).

[2] Liu Xiaohui, Zhang Zhe: A tentative Study on heroes' complex in 'Women in Love', Journal of Huanghe S\&T University, 2011 (6). 
[3] Bi Shiying: Interpretation of Female View from 'Women in Love', Science \& Technology Information, 2012 (14).

[4] Xu Jingzhen: Profound Cultural Implication of Buffet in 'Women in Love', Gansu Social Sciences, 2013 (2). 